\title{
The relationships between knowledge, behavior and environmental education among families from vulnerable socioeconomic conditions
}

\author{
As relações entre conhecimento, comportamento e educação ambiental entre famílias de condições \\ socioeconômicas vulneráveis
}

Las relaciones entre conocimiento, comportamiento y educación ambiental entre familias de condiciones socioeconómicas vulnerables

Received: 08/05/2021 | Reviewed: 08/10/2021 | Accept: 08/11/2021 | Published: 08/15/2021

Sebastian Neuhaus
ORCID: https://orcid.org/0000-0001-9785-806X
Osnabrück University of Applied Sciences, Germany
E-mail: neuhaus.sebastian@yahoo.de
Rebecca Sommer
University of Bonn, Germany
ThCID: https://orcid.org/0000-0002-4799-2962
E-mail: rebecca-sommer@web.de
Thayse Diniz Pedrosa
ORe
ORCID: https://orcid.org/0000-0002-5769-7668
Federal University of Pernambuco, Brasil
E-mail: thaysediniz1@hotmail.com
Armando Dias Duarte
ORCID: https://orcid.org/0000-0003-2571-7705
Federal University of Pernambuco, Brasil
E-mail: armando01.dias@gmail.com
Osmar Veras Araujo
ORCID: https://orcid.org/0000-0001-9877-8088
Federal University of Pernambuco, Brasil
E-mail: armando01.dias@gmail.com
Gilson Lima da Silva
ORCID: https://orcid.org/0000-0003-2484-3590
Federal University of Pernambuco, Brasil
E-mail: glimasilva21@yahoo.com.br

\begin{abstract}
Education is built in the environment in which the individual is inserted and through learning, values and beliefs are responsible for personal development. Among different educational contexts, environmental awareness can be considered as one of the bases for promotion in different family groups, and with that, it can improve the implementation of environmental practices in society. The study aimed to analyze the profile of different families of those participating in the environmental project, ASA sustainable school, located in the city of Caruaru-PE. For the development of the research, visits were carried out in the houses of the families and through the application of a quantitative questionnaire, the responsible person answered them. According to the analysis of the necessary information, $85 \%$ of adults attended school only until the end of elementary school, and $15 \%$ of the cases, those responsible attended to literacy. Regarding environmental awareness, $78.57 \%$ of the families are interested in environmental issues and already carry out practices aimed at sustainability, but above the intensification and incentives for a better performance of practices that are already commonplace.
\end{abstract}

Keywords: Environmental awareness; Environmental practices; Social and environmental reality.

\section{Resumo}

A educação é construída no ambiente em que o indivíduo está inserido e através da aprendizagem, valores e crenças são responsáveis pelo dedesenvolvimento pessoal. Dentre diferentes contextos educacionais, a consciência ambiental pode ser considerada como uma das bases para a promoção nos diferentes grupos familiares, e com isso, pode melhorar a execução de práticas ambientais na sociedade. O estudo teve como objetivo analisar o perfil de diferentes famílias dos que participam do projeto ambiental, ASA escola sustentável, localizado na cidade de Caruaru- PE. Para o desenvolvimento da pesquisa, visitas foram realizadas nas casas das famílias e através da aplicação de um questionário quantitativo, o responsável familiar as respondia. De acordo com a análise das informações obtidas, $85 \%$ dos adultos frequentaram a escola apenas até o final do ensino fundamental, e $15 \%$ dos casos, os responsáveis cursaram até a 
alfabetização. Sobre a conscientização ambiental, 78,57 \% das famílias têm interesse em questões ambientais e já realizam práticas que visam a sustentabilidade, mas necessitam da intensificação e incentivos para uma melhor realização de práticas que já corriqueiras.

Palavras-chave: Consciência ambiental; Práticas ambientais; Realidade socioambiental.

\section{Resumen}

La educación se construye en el entorno en el que se inserta el individuo y mediante el aprendizaje, los valores y creencias son responsables del desarrollo personal. Entre diferentes contextos educativos, la conciencia ambiental puede ser considerada como una de las bases para la promoción en diferentes grupos familiares, y con ello, puede mejorar la implementación de prácticas ambientales en la sociedad. El estudio tuvo como objetivo analizar el perfil de diferentes familias de los participantes del proyecto ambiental, escuela sostenible ASA, ubicada en la ciudad de Caruaru-PE. Para el desarrollo de la investigación se realizaron visitas en las casas de las familias y mediante la aplicación del cuestionario cuantitativo, el responsable las respondió. Según el análisis de la información necesaria, el 85\% de los adultos asistieron a la escuela solo hasta el final de la escuela primaria, y el 15\% de los casos, los responsables asistieron a la alfabetización. En cuanto a la conciencia ambiental, el $78,57 \%$ de las familias están interesadas en temas ambientales y ya realizan prácticas desde la sostenibilidad, pero por encima de la intensificación e incentivos para un mejor desempeño de prácticas que ya son comunes.

Palabras clave: Conciencia ambiental; Prácticas ambientales; Realidad social y ambiental.

\section{Introduction}

The ultimate aim of education is shaping human behavior" (Hungerford; Volk, 1980). Environmental Education (EE) has been defined by the Tbilisi Intergovernmental Conference on the Environmental Education (EE) as follows: to help social groups and individuals acquire awareness, sensitivity, knowledge, and the understanding of environmental problems, proenvironmental values and concerns, skills to identify and solve environmental problems, and finally, to provide opportunity to be actively involved (Unesco/ Unep, 1977). Furthermore, according to Pereira; Dinardi and Pessano (2020), EE can be applied at different levels of education and different ages, as stated by Vasques and Messeder (2020) and Costa; Nascimento and Azevedo (2020).

Looking at the worldwide increasing environmental destruction and degradation, the accelerating climate change through almost unlimited greenhouse gas-emissions, the overfishing of the oceans and the steady replacement or endangerment of maritime life through plastic waste, one might ask if the last 50 years of EE have mostly been without success. Surely, this is a rhetorical question and certainly great progress has been achieved on many issues, but one question remains: Why do many EE programs fail to show the impact they were supposed to have?

This paper tries to shed a light on one of the limiting factors of the EE success which is the home environment of children, their families' habits as well as the ideas their families have on issues such as environmental protection. Families and especially parents play a crucial role in the development of values and behaviors related to the environment of their children (Grønhøj \& Thøgersen, 2009). To follow this question a comprehensive questionnaire has been developed which asks - inter alia - about socio economic factors, the families' environmental consciousness and a variety of habits such as water and energy usage, transportation and rubbish disposal. The questionnaire was applied in 14 homes of families whose children attend the fifth grade in a public school and participate in an EE program carried out by the group "AMA" from the Federal University of Pernambuco. In the following, the methodology of this study will be laid out, terms will be defined and an overview about the research on factors limiting the impact of EE will be given. This will be followed by an analysis of the answers given and a discussion and interpretation of the findings. Also, the limitations of this study need to be discussed.

\section{The Relation of Knowledge and Behavior}

Contrary to public believe, additional knowledge on environmental issues does not necessarily increase environmentfriendly behavior. Early Environmental Behavior-models (EB-models) assumed that equipping people with (Environmental 
Knowledge (EK) would automatically lead to increased environmental awareness and ultimately foster EB (Kollmuss \& Agyman, 2002). Traditionally EE was based on this so called information-based approach, ultimately attempting to increase a person's formal knowledge and ability to achieve a higher score in a knowledge test. Those models of linear progression were soon proven to be wrong, though even today many environment awareness-campaigns are still based on the assumption that informing the public will automatically lead to behavior changes. Simmons and Volk (2002, p. 7) for example quote the EEeducator Harold Hungerford: "We still believe - so very strongly - in the knowledge > attitude > behavior model of learning when, at the same time, we know how desperately inadequate this is when it comes to changing the citizenship behaviors of large numbers of learners over long periods of time."

Several studies have identified a variety of gaps hindering the development of EB through increased EK. Rajecki (1982) found the following four causes for the missing link between EK and EB: direct versus indirect experience of environmental problems; the normative influence through social norms, cultural traditions or family customs; temporal discrepancy between the measurement of attitudes and the data collection for the behavior; disproportions between the measurement of attitude and behavior. Kaiser and Fuhrer (2003) have suggested that the definition of knowledge has been to narrow and unidimensional and that EE-research as well as EE itself should incorporate a variety of knowledge-forms, specifically declarative, procedural, effectiveness and social knowledge. Carmi et al. (2015) found, that neither formal nor informal knowledge have a direct influence on environmental behavior. However, both formal and informal knowledge were significant and fully mediated by environmental emotions, meaning that emotions might play a crucial role in reaching the goal of EE which is ultimately the adoption of EB.

Grønhøj and Thøgersen (2009) found a strong intergenerational transmission of values, attitudes and behaviors on environmental topics between parents and their children. Their findings show a significant correlation especially at the level of specific environmental attitudes and behaviors and to a lesser extent at the level of general and abstract values. Their work suggests that household practices, parent's behavior and their attitudes towards environmental topics hold implications for the design and execution of EE. Their findings can be interpreted as a validation for Rajeck's (1982) assumption, that the normative influence especially of family customs has a strong influence on the formation of personal attitudes and behavior. Some research suggests a rather bi-directional influence between parents and children, though the overall results remain inconclusive (Damerell et al., 2013). Vaughan et al. (2003) for example found a knowledge transfer from children participating in a macaw's education program to their parents. Legault and Pelletier (2000) however found no prove of behavioral influence from children on their parents, while Damerell et al. (2013) found that children influence not only their parent's knowledge but also behavior.

In summary research suggests a strong influence of families on the behavior and values of children in relation to the environment. Children might just as well have influence on their parents, but research is still inconclusive. This might also hold implications for EE-programs, especially when families show little interest in environmental issues and do not put great concern on environmental behavior. Children from those families might be less open to accept the input given through EE and therefore EE-programs would show less to no effect, because the socialization of children can hardly be thrown overboard by a few EElessons. On the other hand, families which show great interest for environmental issues and already practice environment-friendly behavior would be great news for EE, since there might appear connections between EE and the household reality of children which could be used to increase the impact of EE in values and practices of the EE-participants.

\section{Methodology}

In order to conduct this research 14 families in the neighborhood of Salgado in Caruaru, a city in the north-east Brazilian state of Pernambuco, have been interviewed. All families have in common, that one or more of their children attend a public school in the suburb and participate in the same Environmental Education Program. The program, called "Amigos do Meio Ambiente" (AMA), is implemented by students from the Campus Academic Center of Agreste, short CAA, of the Federal 
University of Pernambuco (UFPE) with the goal to increase the environmental knowledge and awareness of pupils and create a better future in accordance with the environment (Andrade et al., 2019). The city of Caruaru has a population of about 351,000, its main economic sectors are the clothing industry and one of the biggest public markets in Brazil called the "Feira de Caruaru". The average monthly income per person (over ten years of age) is about $R \$ 549.75$ (Caruaru, 2019), the average monthly salary of formal workers is about 1.7 minimum wages (IBGE, 2017).

The work developed was considered a case study based on the precepts of Yin (2015), whose focus was the analysis of the pupil's families in relation the environmentally relevant behavior and their sensibility and openness to questions of environmental protection. For data collection a standardized questionnaire was used, which was partly based on a prior work of Duarte; Bezerra and Gonçalves (2021) which investigated the insalubrity of households in the same suburb. Questions on the environmental sensibility of the families were added. All but three questions were closed questions. The questionnaire was designed to be answered by adults of the family, assuming this person can give representative answers for the family.

For the application of the questionnaire a quantitative interview method was used. This method is a common instrument for measuring in social sciences and according to Pereira et al. (2018) the questionnaire allows the possibility of reaching a large number of interviews and guaranteeing anonymity. The mixture of close and open questions leads to quantifiable as well as individual answers. Open questions are used to ask for the respondent's answer in his or her own words or for his or her own ideas and knowledge (Meier Kruker \& Rauh, 2005). In the case that all possible answers are already known by the researchers, closed questions are used. If so, the interviewee has to choose one or more of the response options. The comparability between answers is higher as well as the saving of time during the survey and evaluation than with open questions (Meier Kruker \& Rauh, 2005). To ensure a level of standardization and comparability the questions were developed with a multiple-choice format (Codó, 2008).

In order to guarantee an adequate response quality and to prevent tiredness the implementation of the questionnaire should not take more than 30 minutes (Codó, 2008). Furthermore, the questions need to be short and self-explanatory. During the conduction of the interviews it was noted, that some of the interviewees had difficulties to understand the questions. Therefore, all questions were read out, in case of uncertainty the questions were explained or rephrased. Answers were given orally and filled in the questionnaire by the researches. The questionnaire consisted of 42 questions, three of which were open and three more offered the possibility to add a personal response besides the preselected. The remaining 36 questions were closed multiple-choice questions. The first part dealt with socioeconomic factors like the educational achievement or household income, the second part treated the environmental awareness and consciousness. This section also contained a self-evaluation about their opinion on environmental topics. The final part consisted of five groups of questions all treating different aspects of environmentfriendly behavior, specifically water, sanitation, waste and energy. For conducting the interviews, groups of two to six researchers visited the families' houses on weekdays as well as weekends. The days were chosen in order to give employed adults an equal chance to participate in the study.

\section{Results and Discussions}

The questionnaires were assessed by using a simple non-statistical evaluation. A statistical evaluation was discussed, but due to the relatively small number of interviews conducted the plan was discarded. In terms of socioeconomic factors, the results are as follows: $85 \%$ of the adults attended school only until finishing elementary school, in $15 \%$ of the cases or 2 families the adults only received an alphabetization. The majority (64\%) of the households receives a monthly salary of less than one minimum salary (MS), $29 \%$ receive a salary of between one and two MS and only one family had an income above three MS. In about $65 \%$ of the households all adults were in employment, in nearly a quarter of the households one adult was unemployed and in two cases two or more people were unemployed. $64.28 \%$ of the households consisted of four or five people, in $21 \%$ of 
the houses lived more than five people. The following part treats the environmental awareness of the families. According to the questionnaire $71.43 \%$ of the respondents attach high to very high importance to environmental protection in their life, only one person rates environmental protection as being of minor importance. Similarly, $78.57 \%$ are interested in environmental issues. Most of them inform themselves via internet $(72.73 \%)$ or television $(54.55 \%)$, some use social networks (36.36\%) and others are informed by friends and family $(27.27 \%)$.

All prior questions were closed, the next three questions were the only open questions and the responses differ substantially from what could be expected after reviewing the above-mentioned response patterns. Questions were asked about environmental problems at various spatial levels. The first question asked about the interviewee's opinion on environmental problems in the surrounding area (street and house). Nine out of 14 people knew an answer, three of them with help by the interviewers, five people knew no answer. Responses ranged from waste and sewage water to the lack of trees (twice) and air pollution (once). The second open question dealt with environmental problems in the city, again nine out of 14 people know an answer, three of them with help. This time the town's river Ipojuca was stated as well as waste and missing trees. One person mentioned mosquitoes. In the third open question the respondents were asked about environmental problems in Brazil and worldwide. Eight people knew an answer to the question, three of them with help. Most of them were particularly aware that there is an environmental problem in the oceans, just two mentioned plastic. Deforestation was stated one time, the Amazonas another time. Moreover, the respondents refer to oil on beaches and missing recycling systems.

In the next step the interviewees were asked to evaluate their own environmental behavior. The majority considered themselves to be moderately environmentally conscious (42.86\%), only $14.29 \%$ ascribed themselves a highly environmentfriendly behavior. All but one family expressed the willingness to live with a higher environmental awareness. When asked about limiting factors for an increased environment-friendly behavior, $69.23 \%$ stated the lack of time, $15.38 \%$ refer to their lowincome or the social surrounding. Knowledge, infrastructure, health and occasion were named one time each.

For the next question the respondent had to choose three out of eight given items which they considered to be of importance for their life during the next 10 years. The items were: money, health, environmental preservation, a new car, their own house, education, happiness and love. Environmental protection was chosen by $50 \%$ of the respondents, love as well. These items were surpassed only by health, which was named by all respondents. Other items were own house, education, happiness, money and an own car. They were selected in the mentioned order. While about $42.86 \%$ of the respondents felt affected by water scarcity and even $57.14 \%$ by air pollution, only $35.72 \%$ felt concerned by pollution through waste.

The next sections treated the supply as well as the usage of water and energy of the households. $85.71 \%$ stated to receive water one or two times per month via water trucks, the houses of two families were connected to the central water supply network. The majority $(92.86 \%$ ) reutilizes water. For drinking and cooking half of the families utilize water from water trucks, $42.86 \%$ buy drinking water in bottles. At a quarter of the families houses sewage water could be found in the surrounding area. $43 \%$ or six houses had irregularly disposed waste near the house. This could be connected to the lack of appropriate storage facilities for household waste in the neighborhood. $78.57 \%$ of the families deposit their waste on the ground in front of their houses before pickup where it is easily accessible for cats and dogs. In terms of waste separation only $28.57 \%$ of the respondents practice waste separation, $71.43 \%$ did not. Only $14.29 \%$ stated to be using disposal services for the adequate disposal of batteries and electronic devices. However, nearly $45 \%$ dispose used kitchen oil in the garbage and not in the sink. $64.28 \%$ eat meat one or more times a day, $30 \%$ consume meat two or three times a week. None of the families interviewed exclusively eat vegetarian or vegan food. For transportation $72 \%$ of the families mostly utilize public transportation, the bicycle or walking. $29 \%$ of the families use the car or motorcycle. The families were also asked to present their last energy bill in order to compare the household's energy consumption. On average a household consumed $107 \mathrm{kWh}$ or $21.65 \mathrm{kWh}$ per capita per month. None except 
one family possessed an electric shower. Almost half of the respondents stated to leave electronic devices turned on while not in use.

According to the Brazilian Institute of Geography and Statistics (Ibge, 2017), the average monthly salary of formal workers in Caruaru is about 1.7 minimum wages. Nine out of 14 families lie beneath this level and only one family well above it. I accordance with the Brazilian system of economic classes nine families are part of the lowest group E, four are part of the group D and only one family is part of the group C (CPS). Most of the families therefore belong to the lowest economic class of Brazilian society. At first glance, the respondents' environmental awareness seems to be high: The importance of environmental protection is rated as high, the majority are interested in environmental issues and are willing to live with a higher level of environmental awareness. In addition, environmental protection will play an important role for half of the families over the next ten years. After a look at the open-ended questions it seems to be different. First, only about $40 \%$ of the interviewees were able to give an answer to the question of current environmental problems in their neighborhood or in general without any help. Assuming that high interests in environmental topics result in a higher level of information, this appears to be surprising. As a result, most respondents should have at least a limited idea about environmental issues. Since the respondents knew that the interviewers were part of a research group on the environment, it is possible that the first responses were influenced by this information. Thus, the answers given at the above-mentioned questions might show a strong social desirability bias. Second, when environmental problems were mentioned, they were almost always related to problems in the everyday life of the interviewees. The question was to define environmental problems in general, the interviewees named oceans, plastic, deforestation, Amazonas, oil on beaches and missing recycling systems. These are all present problems in this region. The questionnaire was implemented at a time, where oil on beaches was a recurrent topic in news as well as wild fires in the Amazonas region (O Globo 2019; Rickly \& Marques 2019). Waste on streets and in rivers as well as missing recycling systems are a big problem in many Brazilian cities. The river Ipojuca which crosses the city of Caruaru is one of the most polluted rivers in Brazil (De Carvalho Filho, 2019). Other problems like climate change, species extinction or soil erosion were not mentioned. They do not affect the people's life directly, therefore presumably, many people do not think about it or do not even know, that there is a problem. Also, some responses did not mention a concrete problem. "The oceans" or "the Amazonas" were repeated answers, though they do not refer to a specific environmental problem. Therefore, we assume that some interview partners are aware of the fact, that in those areas environmental problems occur, but they lack the information or do not have reflected the precise issues.

Thirdly, when asked about the way to obtain information, $55 \%$ responded with "television". Since television constitutes a rather passive form of receiving information, we assume, that the respondents, even though they might have an interest in environmental issues, are not driven through this motivation to inform themselves proactively.

However, the examined families do show a lifestyle which can be considered to be rather environment-friendly. They reutilize and economize water, dispose the used kitchen oil adequately or collect it, have a low energy consumption, and use mostly public transport, bicycle or are walking by foot. It remains the question about the families' motivation on these activities. Due to the mostly relatively low-income and missing water infrastructure we assume, that the reason for these environmentfriendly behaviors are not the awareness of environmental problems but rather a consequence of missing financial resources and a lack of infrastructure. For instance, the reutilization of water might be an expression of the lack of a constant water supply and limited storage capacities for the water that is delivered by water trucks. Since the families only receive water one or two times a month, it must be used sparingly and logically results in reuse. In addition, water shortage was not mentioned as an environmental problem. This suggests that the interviewees are not aware of the problematic water shortage in the region. This assumption is supported by one more fact: There is a strong division between behaviors which depend either on financial resources or infrastructure and behaviors which are mostly independent from these factors. As described the interviewees mostly 
showed EB in relation to water usage or relatively expensive customs such as using a private car/ motorcycle or utilizing an electric showerhead, but customs which do not depend on the above-mentioned factors show rather little to no indication for environment-friendly behavior. Over $70 \%$ do not separate waste, $50 \%$ throw batteries and electronic devices into the household waste and $50 \%$ do not turn off electric device when not in use. These numbers indicate that the strongest motivations for environment-friendly behavior are either the adaptation to infrastructure limitation or the lack of financial possibilities. This topic can be another easy way to help the environment. The question is, why the people throw electric devices into the waste. According to their answer about the limits, it is because of missing time to go to the collection point. This requires the precondition of knowledge about the bad consequences for the environment due to disposal in common waste.

However, it needs to be noted that the studied families already belong to a group with a comparably low consumption and therefore low environmental impact. The energy consumption of the households lies well below the national average and a majority does not own a car or motorcycle. Due to the relatively low household income of most families it can also be assumed, that in general the families consume less goods, which would result in significantly lower resource consumption, land usage and $\mathrm{CO} 2$-emissions. This is obviously not a new finding, since less money automatically results in less consumption. However, it is important to note, that the major influence on the environment does not emanate from low-income families but from richer ones, who have a higher per capita consumption of goods and services. Since in Brazil the majority of children from wealthier families attend private schools, the implementation of the EE-program in private schools should be discussed.

\section{Final Considerations}

It is important to notice, that all the results must be analyzed carefully because the amount of studied families is too small to be representative. Nevertheless, the results can provide an interesting insight into the situation of families and can potentially provide important information for adapting and improving EE programs. Summarizing the findings of this work it must be said that the examined group of people show some highly environment-friendly behavior and have a comparatively low resource consumption, at least in the researched areas. Though there are certain behaviors which could be changed to further reduce the environmental impact of the questioned families, overall there is little room for improvement. Our findings on the environmental consciousness are somewhat inconclusive. Even though the families expressed great interest in environmental issues and wished to do more to protect the environment, the open questions from the questionnaire suggest a relatively strong social desirability bias. A suggestion for the further development of AMA's EE-program could be to put a stronger emphasize on environmental issues which directly impact the life of the families and therefore the children, such as river pollution or inappropriate waste disposal. Putting an emphasize on these issues would strengthen the link between the children's actual experiences and the program, therefore hopefully also increasing the impact of program.

The present work certainly has some limitations. Firstly, the number of interviews conducted limits the information value of the results. Even though this research is a case study of the living situation of one school class which participated in an EE program, the 14 interviews do not even include half of the student's families. Unfortunately, we were unable to conduct a higher count of interviews since many addresses supplied by the school as well as by the students turned out to be wrong or the given addresses could not be found due to inaccurate city maps which sometimes did not include streets or house numbers. In fact, the 14 interviews conducted include almost all houses we encountered. Due to the relatively low number of interviews conducted, the planned statistical analysis would not have led to conclusive and significant findings. Furthermore, the families' children attend a public school in a relatively underdeveloped neighborhood with a, in economic terms, mostly homogenous population hence the limited diversity of the answers given. Nevertheless, we consider our results to be exemplary for many lowincome families which face the same economic challenges. The questions on environmental awareness are likely to be influenced by the background of the interviewers. For interviewing the family's, the interviewers had to present themselves and through 
their children the parents already knew some facts about the program and their aim. There can be differences between the available information because it is not manageable which information a kid gives to his parents.

As suggestions for future work, they are: to increase the number of interviews, apply the questionnaire to other school realities, in different schools and check if the addresses are updated in the school records. Therefore, the previous knowledge of the interviewees can be different. Moreover, it would be interesting to analyze the situation in higher income families to compare the environmental behavior of both. Afterwards, the program's implementation in private schools can be helpful to foster the impact of EE in Caruaru and Brazil-wide.

\section{References}

Agyeman, J., \& Kollmuss A. (2002). Anja: Mind the Gap: Why do People Act Environmentally and what are the Barriers to Pro-environmental behavior? Environmental Education Research, 8 (3), 2002, 239-260.

Andrade, G. N. et al. (2019). Aplicação da Metodologia G5 Ambiental em escolas da Rede Pública de Caruaru-PE Em 2019: Um Estudo De Caso. VI Congresso Nacional de Educação (CONEDU).

Carmi, N., Arnon, S. A., \& Orion N. (2015). Transforming Environmental Knowledge Into Behavior: The Mediating Role of Environmental Emotions, The Journal of Environmental Education, 46 (3), 183-201.

Caruaru (2019). Visite Caruaru. Dados Socioeconómicos e Geográficos. http://visitecaruaru.com.br/pt/Sobre_Caruaru/Dados_Socioecon omicos_e_Geograficos/10/

Codó, E. (2008). Interviews and Questionnaires. Published in: WEI, L. a. M. G. MOYER (eds): The Blackwell Guide to Research Methods in Bilingualism and Mulitlingualism. 158-176. https://www.researchgate.net/publication/229711234_Interviews_and_Questionnaires

Costa, R. F. da S., Nascimento, F. de L. S., \& Azevedo, P. G. (2020). The Common National Curricular Base and Environmental Education: Advances and setbacks regarding Recommendations for Geography Teaching in Elementary Education. Research, Society and Development, 9 (1), e77911654. https://doi.org/10.33448/rsd-v9i1.1654

Damerell, P., Howe, C., \& Milner-Gulland, E. J. (2013). Child-orientated environmental education influences adult knowledge and household behaviour. Environmental Research Letters, 8 (1), 015016.

Duarte, A., Bezerra, S., \& Gonçalves, E. (2021). Environmental health indicator for the evaluation of neighborhoods in urban areas: a case study in Caruaru (PE), Brazil. Brazilian Journal of Environmental Sciences (Online), 56 (1), 166-179. https://doi.org/10.5327/Z21769478750, 2021.

De carvalho filho, J. A. A. (2019): Estudo de contaminantes emergentes e meiofauna no Rio Ipojuca no Município de Caruaru. https://repositorio.ufpe.br/handle/123456789/33505

FGV Social, Centro de Políticas Sociais: Qual a Faixa de Renda Familiar das Classes? https://cps.fgv.br/qual-faixa-de-renda-familiar-das-classes

Grønhøj, A. \& Thøgersen, J. (2009): Like father, like son? Intergenerational transmission of values, attitudes, and behaviors in the environmental domain. Journal of Environmental Psychology, 29, 414-421.

Hungerford, H. R. \& Volk, T. L. (1980): Changing Learner Behavior through Environmental Education.

Ibge (2017): Instituto Brasileiro de Geografia e Estatística. Caruaru. https://cidades.ibge.gov.br/brasil/pe/caruaru/panorama

Kaiser, F. G. \& Fuhrer U. (2003): Ecological Behavior’s Dependency on Different Forms of Knowledge, Applied Psychology: An International Review, 2004, $52(4), 598-613$

Legault, L. \& Pelletier L. (2000): Impact of an environmental education program on students's and parent's attitudes, motivation, and bhaviors. Can. J. Behav. Sci. 32, 243-50.

Meier Kruker, V. \& Rauh, J. (2005): Arbeitsmethoden der Humangeographie. Geowissen kompakt. (Wiss. Buchges) Darmstadt.

O Globo (eds.) (04.12.2019): Desmatamento na Amazônia aumentou 212 \% em outubro de 2019. https://oglobo.globo.com/sociedade/desmatamento-naamazonia-aumentou-212-em-outubro-de-2019-24116346

Pereira, A. S. et al. (2018). Metodologia da pesquisa cientifica. UFSM.

Pereira, K. B., Dinardi, A. J., \& Pessano, E. C. (2020). The Environmental Education approach in the Pedagogical Project of a Natural Science degree Course. Research, Society and Development, 9 (8), e101985200. https://doi.org/10.33448/rsd-v9i8.5200

Rajecki, D.W. (1982): Attitudes: themes and advances (Sunderland, MA, Sinauer).

Rickly, A. \& Marques J. (2019): Fragmentos de óleo são encontrados em praias de Cabo Frio, no RJ. https://g1.globo.com/rj/regiao-doslagos/noticia/2019/11/28/fragmentos-de-oleo-sao-encontrados-em-praias-de-cabo-frio-no-rj.ghtml

Simmons, B. \& Volk, T. (2002): Environmental Educators. A Conversation with Harold Hungerford. The Journal of Environmental Education, 34 (1), 5-8. 
Research, Society and Development, v. 10, n. 10, e421101019125, 2021

(CC BY 4.0) | ISSN 2525-3409 | DOI: http://dx.doi.org/10.33448/rsd-v10i10.19125

Unesco/ Unep (1977): The Tbilisi Declaration. https://www.gdrc.org/uem/ee/tbilisi.html

Vasques, C. C., \& Messeder, J. C. (2020). Environmental Education in a reflexive perspective in Young and Adult Education. Research, Society and Development, 9 (8), e113984782. https://doi.org/10.33448/rsd-v9i8.4782

Vaughan, C., Gack, J., Solorazano, H. \& Ray, R. (2003): The Effect of Environmental Education on Schoolchildren, Their Parents, and Community Members: A Study of Intergenerational and Intercommunity Learning, The Journal of Environmental Education, 34 (3), 12-21.

Yin, R. K. (2015). O estudo de caso. Bookman. 